\title{
Language change under different approaches
}

\begin{abstract}
Depending on the point of view, changes can have small or large consequences on a system. Regarding human language, we see this kind of relativism in a claim made by linguist David Lightfoot: language change can be considered abrupt if we focus on its internal properties or gradual if we focus on external ones. Two well documented cases of language changes, usually described as transitions from null to overt pronominal subjects in Old French and in modern Brazilian Portuguese, are used as empirical analyses for our evaluation of Lightfoot's claim.
\end{abstract}

Fabio Luis Fernandes Mesquita fabio mesa@yahoo.com.br Universidade Tecnológica Federal do Paraná, Curitiba, Brasil.

Ednei de Souza Leal edsleal79@gmail.com Universidade Federal de São Carlos, São Carlos, Brasil.

Keywords: Language change. Null subject. Parametric change. 


\section{INTRODUÇÃO}

Variation is a fact of nature. The concept of species, for example, refers to an abstract category of individuals who share a great deal of common properties but vary in terms of a few others. If the individuals in a system are able to reproduce and transmit some of their properties to their descendants, then we have a dynamical kind of variation, that is, it happens over time. In case this reproduction or transmission happens at different rates, or also if there is any error in the transmission (a mutation), we can say that the system changes.

A change can occur as a rupture or a transition. If we think of individuals having fixed properties $\left(P_{1}\right.$ and $\left.P_{2}\right)$, then transitions involve a period of competition, as shown in Figure 1.

It is possible to think of a collective language in terms of an abstract system in which the individual language of a person (roughly what linguist Hermann Paul called idiolect) is inherited by other people, but overall this transmission process is not uniform and then both the personal and the collective language can change. ${ }^{1}$

Figure 1: Differences between rupture and transition.

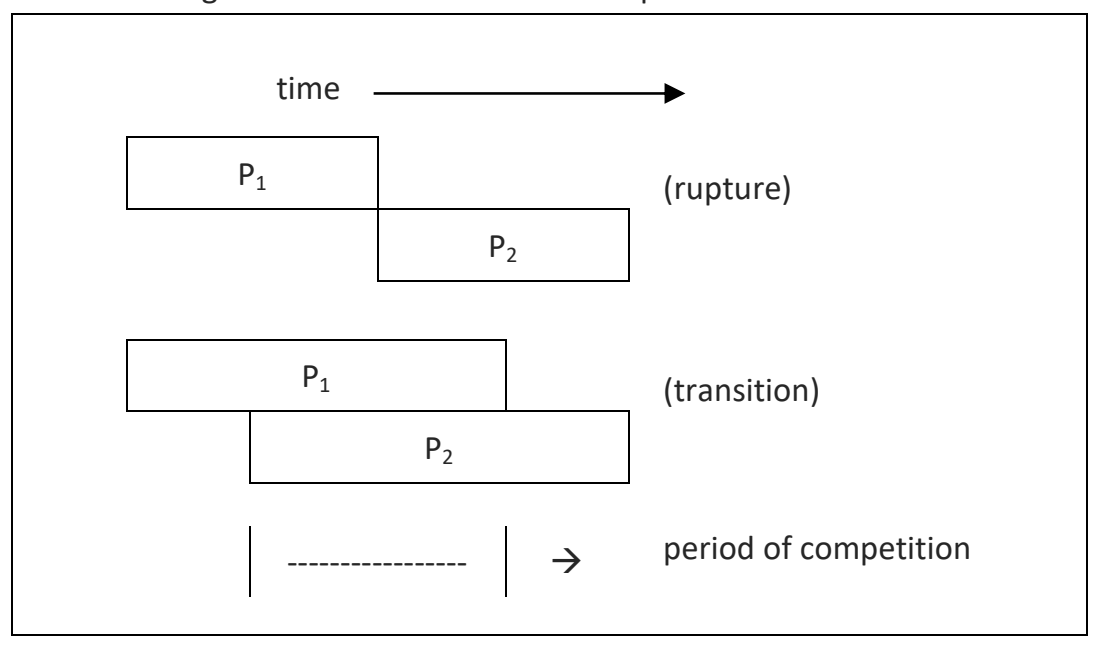

Distinguishing change at a collective level from change at a personal level depends on what part of the system we focus our investigative lens on. See Figure 2: two grammars $\left(G_{1}\right.$ and $\left.G_{2}\right)$ can cohabit in the same person $(A)$, for example. This person would be able to put them to use at different situations, but then imagine that only one of these grammars $\left(G_{2}\right)$ can be transmitted to another person (B). 
Figure 2: Change at personal and collective level.

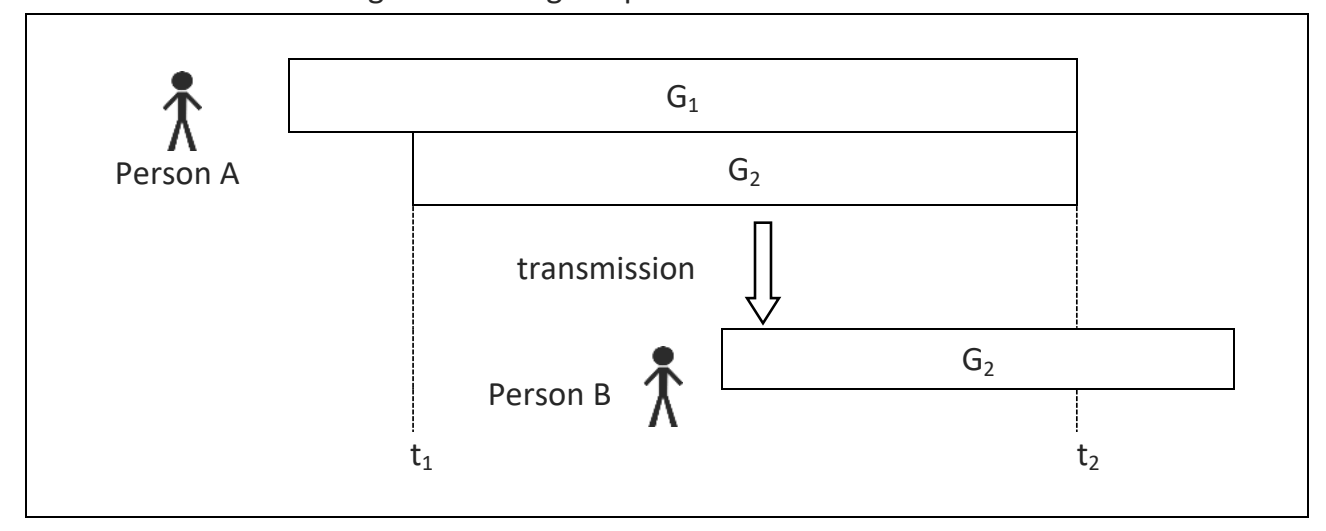

The system is then undergoing two kinds of change: at instant $t_{1}$, person $A$ gets another grammar $\left(G_{2}\right)$, so there is change at personal level. At instant $t_{2}$, grammar $\mathrm{G}_{1}$ ceases to exist, leaving only grammar $\mathrm{G}_{2}$ in the system: we thus have change at collective level (this actually happens at instant $t_{1}$ as well, when the system acquires $\mathrm{G}_{2}$.

So when a person starts using overt subjects in sentences that he/she would not have used it before (due to contact with other dialects, for instance), it can be said there was an abrupt change at the personal level (the acquirement of a nonnull pronominal subject system, for example), even if that person takes some time to fully incorporate the new system. This is only one of the aspects of change that will concern us here.

We are also interested in changes which happen in a system having different grammars across groups of people. And one question will be analyzed more thoroughly:

1) Do languages change gradually or abruptly at the system level?

The analysis of ruptures in collective languages may sound strange at first: most work on linguistic change have been putting forward claims like "syntactic changes may take centuries to establish", for example. We are not claiming that this notion is wrong, given all the well-documented work on long-term changes like the loss of case endings in Latin or how overt subjects became mandatory in modern French, for example.

We want to focus on something more abstract about these facts. First, if we consider the scheme in Figure 2, we can state that collective change entails personal change. The transition at the collective level is the result of changes happening with people at different times. Therefore, when a child acquires a language with a slight different property from his/her family, for example, this can be considered a rupture. As we said, we are directly interested in the consequences of this individual change at the system level: if properties of grammars are taken to be fixed, then transition entails rupture. See Figure 1 again: the transition there results from ruptures happening at different times. 
In the next section, we will discuss the effects of envisioning abstract internal properties of a complex system like language. In section 2 , we will see how studies assuming parametric variation helped to shed some light on linguistic change studies. Sections 3 and 4 bring empirical analyses of linguistic changes in French and Brazilian Portuguese, respectively. Concluding remarks are in the last section.

\section{ZOOMING IN ON LANGUAGE}

We actually already have a preferred answer to the question 1) posed above. Concerning language change, we see abrupt and gradual as aspects of the same phenomenon. This view follows from a proposal made by David Lightfoot:

[...] I'll argue here that whether or not change is generally gradual depends on what units of analysis are employed and which lens is used. It is languages which change gradually; grammars are a different matter. If we use biological grammars as our unit of analysis, then abrupt change happens. (LIGHTFOOT, 1999, p. 83)

In order to fully accept or decline the author's proposal, however, it is necessary to understand what he calls "biological grammar". The term 'biological' is to be taken here as 'seriously biologically constrained'. If we think about it, every aspect on every organism is somehow constrained by its biological constitution (try to fly only by flapping your arms, for example). The point of high controversy about language being biologically determined is how direct would the influence of the genetic program be on language behavior.

Lightfoot believes this influence is so strong that it would be scientifically possible to describe a universal grammar for humans in terms of a representational system. But, as we will see, even this universal system would allow for variation and, consequently, change. This would be possible by assuming that this system contains parameters to be set by speakers as they acquire language.

There is, however, an important point to make concerning our immediate objective. We are considering here that even if one does not believe in biological grammar claims, Lightfoot's proposal would be still valid provided we abstract away the notion of biological in favor of the notion of internal properties of language. Before we try to define what these are, however, we are going to give a non-empirical argument: probably every complex system can be seen in terms of internal and external properties.

A genetic mutation, for example, is a typical example of rupture. It happens when an organism's DNA replication process fails at some point and the descendants of that organism get a slight different copy of its genetic material. Most mutations end up in no actual or noticeable change in the organism's phenotype, but occasionally the change is effective enough to survive and spread in the population. A consolidated change in the species genotype is what we call evolution. It can happen at a fast or slow pace, but even when it is very fast we are talking about tens of thousands of years.

It is a common story told in historical linguistic studies that small phonological changes can have, therefore, large structural changes over the centuries, like the 
erosion of case endings in Latin leading to more strict word order in modern Romance languages. Depending on the way we see it, the passage of case to nocase endings in Latin nouns can be considered an abrupt change, but the fact that a Romance language like Portuguese shows very little remnants of that system (in some pronouns) is usually thought as a slow gradual change from a Latin to a Romance system.

There is a loose analogy we can make among these biological and linguistic facts which can only work if we are considering abstract mechanisms. Take individuals in a dynamical system, add variation, transmission of properties and competition, and there you have it, a system based on selection that can be applied to almost everything in this universe, from bacteria reproduction to financial investments. The problem with ubiquitous explanations is that they can explain very little in terms of external properties.

So, let us see an example of linguistic theory that aims at a higher purpose: describing internal properties of languages in a way that a reasonable explanation about variation and change can fit in.

\section{PARAMETERS AND VARIATION}

Ancient Greek thinkers like Democritus had some intuition about primordial discrete elements, but before modern chemistry theory, it would be very hard to conclude that all different kinds of matter in the world, from wood to water, were made of the same elements.

It turns out that, after modern chemists had come up with the Periodic Table of elements, we now can say that everything in the (known) universe must be made of the same hundred kinds of atoms. The difference among them is somewhat mathematical: each element in the table succeeds the other by adding one proton to its nucleus. The consequences of having a one-by-one proton scale are not linear, though. It can make chemical properties diverge radically. Chlorine has 17 protons and it can combine with many other elements to create thousands of substances, from gases to plastics. Its successor, Argon, has 18 protons and is a noble element which doesn't fancy reacting with others. Now, this is a great scientific achievement: explaining the wild variation of all physical matter with some universal basic principles.

Baker (2001) proposes that it is possible that human internal language is made of atomic elements, and that, analog to the case of chemical processes, the combination of these atoms is the mechanism responsible for the great variation that is visible in the surface. He suggests that the atoms of language diversity must be what linguists call parameters.

Navajo $^{2}$ and Japanese, two languages that are historically and culturally unrelated, share some characteristics about canonical word order. Sentences in both languages show the following properties: 
1) Ashkii at'ééd yiyiiłtsą. (Navajo)

boy girl saw

"The boy saw the girl"

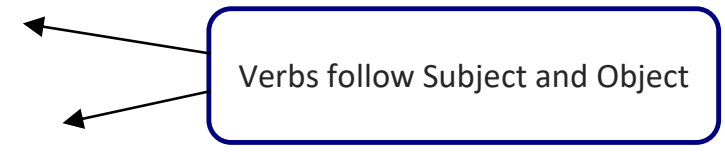

2) John-ga Mary-o butta. (Japanese)

John-SUB Mary-OBJ hit

"John hit Mary"

3) éé biih náásdzá. (Navajo)

clothing into I-got-back

"I got back into my clothes."

NPs inside a PP come before prepositions (or postpositions)

4) John-ga Mary to kuruma da Kobe ni itta. (Japanese)

John-SUB Mary with car by Kobe to went

"John went to Kobe by car with Mary"

5) Chidí bi-jáád. (Navajo)

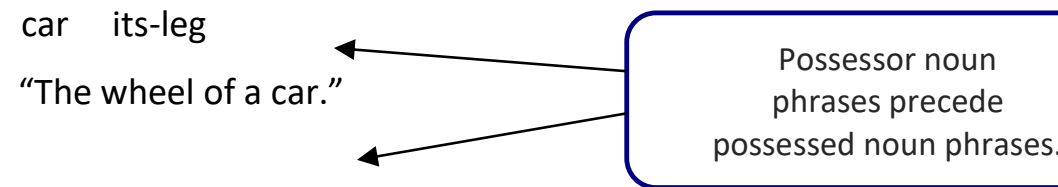

6) John-no imooto-ga sinda. (Japanese)

John-'s sister-SUB died

"John's sister died."

(BAKER 2001, p. 28)

The similarities between Navajo and Japanese show that something very interesting is happening between heads and their complements: the direction in what they appear is the opposite of canonical order in languages like English, Portuguese and Edo (spoken in Nigeria), for example.

Considering the abstract language structure underlying these sentences, we see that some simple head directionality parameter can be postulated to describe these differences: it is set to head final in languages like Navajo and Japanese, and head initial for English, Portuguese and Edo. The opposition between English and Japanese phrase structure can be seen in Figure 3. 
Figure 3: Phrase structure in English and Japanese.

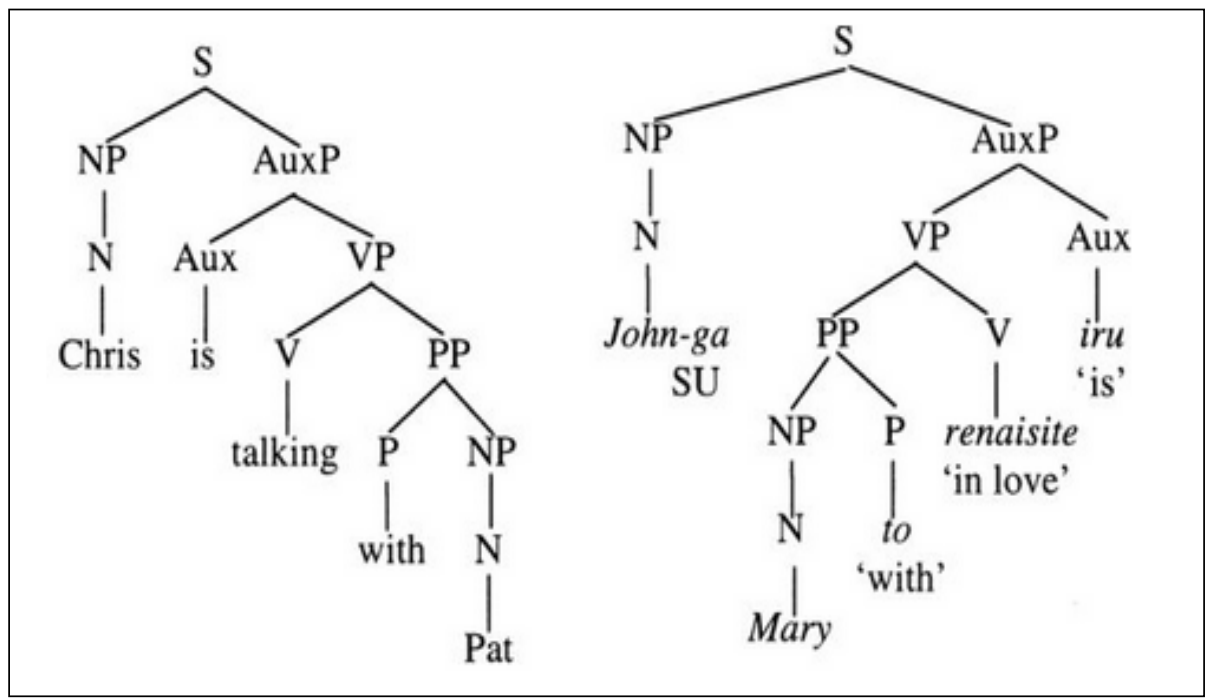

Source: Baker (2001) pg. 76

This idea is not new. It can be traced back to Joseph Greenberg's linguistic universals, which implied that these phenomena involving verb-object and preposition-noun order were interrelated (GREENBERG, 1966). The modern notion of parameter, however, was developed in sophisticated theoretical accounts, and today the conceptions can actually vary among studies (KATO, 2002).

In the beginning, it was usually taken to be a series of abstract syntactic characteristics: Chomsky (1981), for example, proposed that languages with a positive pro-drop parameter would show subject omission, free subject-verb inversion, extraction of distant subjects, among other properties. More modern accounts seem to have narrowed down the notion of pro-drop to something more specific (the properties of a single functional category like AGR, for example).

Still, whatever enterprise based on internal language properties turns out to be successful, it seems that their assumptions brought about facts that previous historicist accounts did not when it comes to describe variation.

The tree below shows one possible historical lineage of Indo-European languages. Although most of the linguistic family relationships are widely accepted as true, the categorization fails to show common grammatical features between unrelated languages. 
Figure 4: Indo-European language tree.

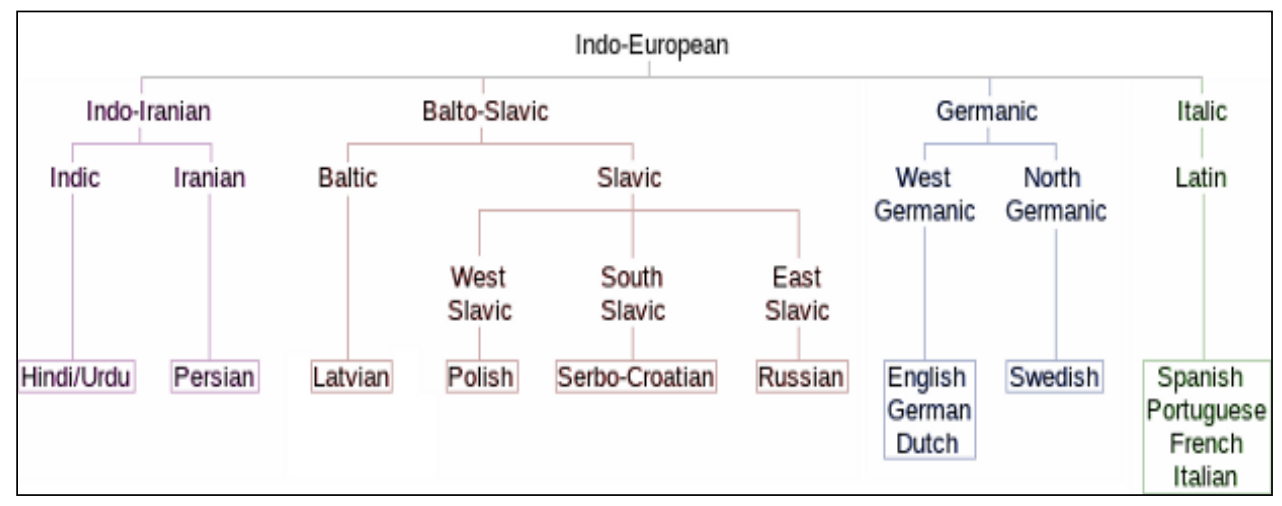

Source: http://www.essential-humanities.net/img/history/indo-european-languagetree.png

The structure above was made possible by the observation of external language features. Therefore, closely related languages show similarities in phonology and lexicon, which are very useful for linguistic studies. However, there must be something interesting going on underneath the surface. Being a head-final language, Hindi, for example, shows more syntactic similarities to distant Japanese than to their head-initial relatives English and Portuguese.

Consider also linguistic change: Old English is similar to modern Dutch and German in many ways. It had four morphological case endings and a phrase order that, some linguists claim (not without controversy), was verb second (V2), and it had a consistent OV system in embedded sentences. Today, Modern English is predominantly SVO, has little fossils from its previous alleged V2 order ${ }^{3}$, and has also lost almost all overt case markings (except for oblique pronouns and the obsolete 'whom'). In that matter, English today resembles more Romance languages like Portuguese than its old relatives German and Dutch, which are still typical V2, case-marked languages (although in Dutch case marking is only used in conservative writing nowadays).

\section{PARAMETRIC CHANGE IN OLD FRENCH}

It is common to hear diachronic accounts about causal chains of morphophonological events that culminate in syntactic change, like in the following story: verb inflection is eroded due to phonological change, therefore making it more difficult for speakers to distinguish person, number and/or gender marked in the verb. So, this modifications in the system would pressure for obligatory use of subject pronouns, which could explain why modern French and English, languages with scarce verb inflection (in their productive oral registers), do not allow null subjects. It would go like this: 
7)

\begin{tabular}{|c|c|c|c|c|}
\hline $\begin{array}{l}\text { verb endings } \\
\text { cease to be } \\
\text { pronounced }\end{array}$ & $\rightarrow$ & $\begin{array}{c}\text { speakers have to cope with ambiguity } \\
\text { because person/number/gender is } \\
\text { not marked in the verb }\end{array}$ & $\rightarrow$ & $\begin{array}{l}\text { subject pronouns can } \\
\text { no longer be omitted }\end{array}$ \\
\hline
\end{tabular}

These facts can indeed be related, but it may not be the whole story. Modern French is a language with non-null subject, but its antecedent, Old French (OF) had plenty of occurrences of empty subjects in matrix clauses until the end of the 15th century, and a rich inflection system. Middle French texts show that both characteristics (empty subjects in matrix and inflections) were fading away at the same rate. So far, these facts match the historical account given above. But something does not fit in: in embedded clauses in OF, the subject was almost always overt, unlike the system of other Romance languages like modern Italian and Spanish:

8) Lors s'acorderent___ $\mathbf{i}^{\text {que }} \mathbf{i l}_{\mathbf{i}}$ diroient que $\mathbf{i l}_{\mathbf{i}}$ l'avoient Then agreed (they) that they would say that they him had

baillié par le commandement Nichodemus. (ADAMS, 1987, p. 2)

in their charge by the commandment (of) Nicodemus.

"Then they agreed that they would say that they had him in their charge by the commandment of Nicodemus."

That is, if phonological erosion of verb endings alone was responsible for changing French into a non-null subject language, why would speakers, before the 15th century, used them profusely in embedded clauses but avoided them in the matrix, as can be seen in the example above?

The regular use of overt pronominal subjects in subordinate clauses is evident from the time of the earliest OF texts, well before the loss of endings [...]. This alone belies the traditional view that phonological erosion of meaningful distinctions forced the use of subject pronouns (Adams 1987, p. 4).

Adams (1987) claims that OF had a V2 system like Germanic languages, which made finite verbs raise to the head position $C$. At this position, the verb governs and has the proper features of agreement for identifying the empty category pro, and therefore the verb at $\mathrm{C}$ licenses pro. The structure in 8) would be then: 
9) [cP Lors C-SPEC $_{\text {s'acorderent }}$ c [IP pro $\mathrm{t}$...

verb raised to $\mathrm{C}$ licenses pro

Following the pattern of some Germanic languages, in OF virtually any maximal projection (XP) could raise to C-SPEC while the verb raised to $C$. This would account for the fact that, in languages with V2 effects, any phrase can precede the inflected verb placed in its perennial second position, and also for the fact that this does not happen in embedded clauses, since $C$ would already contain some complementizer like 'que'.

In 9), the XP which moved to C-SPEC was the adverbial phrase ("Lors"), but in other cases it could be some NP functioning as the subject that raised. This could make sentences appear in the surface as they were SVO, in embedded as well as in matrix. According to Adams, at some point French children started to identify sentences with raised subject and verb as typical of SVO languages.

10)

\section{Adult grammar Learner's reanalysis}

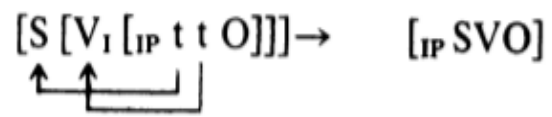

The fact that VO order could apparently be in matrix and embedded clauses for learners made French different from other V2 languages like German and Dutch because these latter had consistent OV order in embedded clauses.

So old French ceased to have V2 effects and therefore could not license pro in the contexts where null subjects occurred. Instead, speakers started using NPs or overt subject pronouns, and they also changed the canonical order into SVO, and the following system probably consolidated by the end of the $15^{\text {th }}$ century.

It seems that one approach can be considered efficient if it yields descriptions of a broad range of linguistic facts in a consistent way. Adams (1987) had interesting results with her account of diachronic facts relying on a theoretical framework conceived under a synchronic perspective, namely generative linguistics. Her attempt, then, can be criticized through many arguments, but it nonetheless represents a good step towards the description of internal properties. Now we are going to take a look at more facts from this perspective.

\section{A HISTORY OF BRAZILIAN PORTUGUESE}

We have seen that pronominal subjects in medieval French were gradually being more expressed as verb inflections decreased, but these facts could be considered independently if another causal phenomenon is postulated (namely, V2 effects in matrix clauses were disappearing). We are now going to look at a 
linguistic change that might be related to these events occurred in French. It happened at a more recent period (between the $18^{\text {th }}$ and $20^{\text {th }}$ century) with another Romance language, Brazilian Portuguese (BP).

At the end of the $19^{\text {th }}$ century some grammatical aspects of BP changed at a fast pace - among them the loss of null subjects on one side, and an increase of null pronomimal objects on the other. In modern sentences, it is much more likely to see overt pronominal subjects in sentences, especially with $1^{\text {st }}$ and $2^{\text {nd }}$ persons:

11) Eu falei que tinha viajado. I said that had traveled.

"I said that I had traveled"

12) Eu falei que eu tinha viajado. (More common today) I said that I had traveled

"I said that I had traveled"

One good way to detect linguistic change is to look for conservative grammarians complaining about it. That was exactly the case about the use of overt subject pronouns at the end of the $19^{\text {th }}$ century:

The habit of always using clear subject pronouns is a vicious Gallicism. I departed; you should not be surprised that they stayed. It would be much more elegant to say: Departed; Should not be surprised that stayed. (RIBEIRO, 1899, p. 299) ${ }^{5}$

Grammarian João Ribeiro was reproaching the attitude of those who, like the French, were pronouncing subject pronouns in every occasion, instead of leaving them silent. He had his reasons to be upset. By that time, overt subject pronouns were flourishing in Brazil.

Some explanations from historical linguists rely on the old association between loss of verb inflection and more occurrences of pronominal subjects, but even those studies usually tell that this could not be the whole story.

First of all, the introduction of pronoun 'você' (you), a form derived from polite ways to address noble people, and the replacement of 'nós' (we) by the expression 'a gente' (the people) both contributed to reduce the number of possible verb inflections because these forms $\left(2^{\text {nd }}\right.$ and $1^{\text {st }}$ person, respectively) agree with $3^{\text {rd }}$ person inflection.

Second, BP showed an increased tendency for null pronominal objects and clitics, which goes in the opposite direction of increasing overt subjects.

These facts are attested by many linguists, so there must be an explanation that connect these facts with another important change: a decreasing number of Verb-Subject (VS) order in the language during the same period. Therefore, the story about verb inversion that happened with French in the $15^{\text {th }}$ century must have had its counterpart in BP by the end of the $19^{\text {th }}$ century.

This is an example of a sentence with VS effects in an interrogative sentence from that period: 
13) O que quer essa mulher comigo? (KATO et. al, 2006, p. 13)

What want ${ }_{v}$ this woman $s$ with-me

"What does this woman want with me?"

At that time, null subjects occurred frequently, so most interrogatives would be like:

14) Onde se esconderia? (KATO et. al, 2006, p. 14)

Where clitic-indeterm would-hide?

"Where would (he/she) hide?"

Kato et. al (2006) claim that due to the fact that in 14) the subject is invisible for a child who is acquiring language, therefore, he/she could interpret the sentence structure in a novel way:

15) $\left[\mathrm{cP}\right.$ Onde [ se esconderia [ip (ela) $t_{v}$ ]]] (adult structure) Where clitic-indet would-hide (she)

16) $\left[{ }_{C P}\right.$ Onde [ [IP (ela) se esconderia ] ] (learner's reinterpretation) Where (she) clitic-indet would-hide

Since the learner is trying to guess where the subject would be, she would prefer (for prosodic reasons, maybe) to put it before $\mathrm{V}$. This model would account for all three phenomena mentioned about linguistic change in BP, namely overt pronominal subjects, null pronominal objects and SV preferred order, telling a similar story to Old French.

\section{CONCLUDING REMARKS}

Assuming that internal properties are straightforward responsible for language change does not exclude the role of morphophonological and other facts from external language. It is visible, for example, that when verbs lost their overt endings in French and Portuguese, subject pronouns were more overtly pronounced, among other facts. It would be insensible to suppose that these events are not connected - historical linguists have been pointing it out for a long time.

Nobody has to believe a priori that an explanation based on parameters is better than the other. Often, a historical account tells a history similar to an internalist account using different concepts. For example, stating that pro has to be licensed by a governing head with the appropriate features can be somewhat equivalent to say that a null subject can occur when the verb carries all the marking of 
person/gender/number in its inflection, if both descriptions are limited to only these facts.

Furthermore, as we have said before about selection mechanisms, parameters are one of those ubiquitous abstract concepts that can be envisioned to have many applications. Depending on the perspective, this can be a disadvantage. Linguists have been working on a good definition of pro-drop parameter for decades, but with the increasing variety of definitions based on other abstract concepts comes the risk of making it an uninteresting concept.

An internalist approach can be more advantageous, due to the fact that it allows observation of new phenomena based on insights provided by internal properties, and/or explain more facts with less theory. Linguists who adopted concepts like functional categories, verb raising and phrase structure sought to explain interesting facts like, for example, the asymmetry between matrix and embedded clauses in the Old French phenomena mentioned in section 3 and connected it with the diachronic change relating to null subjects. Adams (1987) and Kato et. al (2006) showed that the change from a null to overt subject system could have been caused by syntactic change instead of verb phonological erosion, which strongly subverts the traditional story.

Diachronic studies are difficult to conduct because of the ample range where data is to be collected, but research on language change can be extremely helpful for linguists, since their results can corroborate a series of assumptions made by synchronic research. At first sight, positing abstract linguistic concepts like empty categories and parameters may look like a move in the wrong direction: some might say that it would make the search for causes of change even harder because of difficulties with empirical verification. But the effects can be just the opposite: it is a move towards universal explanation. If these hypotheses turn out to be right, they will explain more with less, a desideratum for science. 


\section{MUDANÇA LINGUÍSTICA SOB DIFERENTES ABORDAGENS}

\section{RESUMO}

Dependendo do ponto de vista, mudanças podem ter consequências pequenas ou grandes em um sistema. No caso da linguagem humana, vemos este tipo de relativismo em uma proposta do linguista David Lightfoot: uma mudança linguística pode ser considerada abrupta se focarmos em propriedades internas da linguagem ou gradual se focarmos nas externas. Dois casos bem documentados de mudança linguística, geralmente descritos como transições de sujeitos pronominais nulos para não-nulos em Francês Antigo e Português Brasileiro moderno, são usados como análise empírica para nossa avaliação da afirmação de Lightfoot.

Palavras-chave: Mudança linguística. Sujeito nulo. Mudança paramétrica. 


\section{NOTAS}

${ }^{1}$ Let us clarify our terminology: 'personal' and 'collective' are terms associated with people, or speakers in the case of language. 'Individual' means a unity to be analyzed in a system: it can refer to a grammar, a property or even a person, depending on what you consider your system to be.

${ }^{2}$ Language spoken in the southwestern part of the United States.

${ }^{3}$ Verbs in non-canonical positions like in the sentences "Only in Brazil can we see such things" or "So do I".

${ }^{4}$ Adams (1987) defends that government has some proper direction defined parametrically: in the case of OF, it was set to the right.

${ }^{5}$ Because null subjects are not allowed in English, the translation, for which we are entirely responsible, does not show that both overt and null options in Portuguese were (and still are) grammatical.

\section{REFERENCES}

ADAMS, M. From Old French to the Theory of Pro-Drop . In: Natural Language \& Linguistic Theory Vol. 5, No. 1, p. 1-32, 1987. Disponível em: $<$ http://link.springer.com/article/10.1007/BF00161866>.

BAKER, M. C. The Atoms of Language: The Mind's Hidden Rules of Grammar. New York: Basic books, 2001.

CHOMSKY, N. Lectures on Government and Binding: The Pisa Lectures. Holland: Foris Publications. Reprint: 7th Edition. Berlin and New York: Mouton de Gruyter, 1981.

GREENBERG, J. 1966. Universals of Language. Cambridge, Mass.: MIT Press.

KATO, M. A evolução da noção de parâmetros. DELTA [online], vol.18, n.2, pp. 309-337, 2002. Disponível em:

$<$ http://www.scielo.br/scielo.php?script=sci arttext\&pid=S010244502002000200006>.

KATO, M.; S. DUARTE, M.E.; CYRINO, S. \& BERLINCK, R. "Português brasileiro no fim do século XIX e na virada do milênio" In Suzana Cardoso, Jacyra Mota e Rosa Virgínia Matto e Silva (orgs.) Quinhentos anos de história lingüística no Brasil. Salvador, Empresa Gráfica da Bahia/Funcultura/Governo da Bahia. pp. 413-438, 2006. Disponível em:

$<$ http://www.unicamp.br/iel/site/docentes/cyrino/KACYDURO\%20com\%20cit.pdf $>$. 
LIGHTFOOT, D. The development of language: acquisition, change and evolution. Malden: Blackwell, 1999.

RIBEIRO, J. Grammatica Portugueza. Rio de Janeiro: Livraria Clássica de Alves \& Co., 1889.

Recebido: 30 out. 2015

Aprovado: 06 ago. 2017

DOI: $10.3895 /$ rl.v19n25.3275

Como citar: MESQUITA, Fabio Luis Fernandes; LEAL, Ednei de Souza. Language change under different approaches. R. Letras, Curitiba, v. 19, n. 25, p. 19-34, jan./jun. 2017. Disponível em: <https://periodicos.utfpr.edu.br/rl>. Acesso em: XXX.

Direito autoral: Este artigo está licenciado sob os termos da Licença Creative Commons-Atribuição 4.0 Internacional.

\section{(c) (i)}

